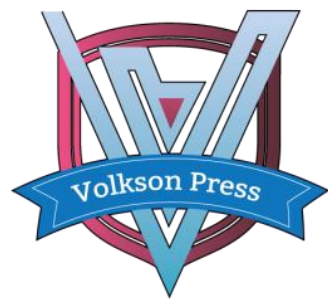

\title{
DESIGN AND OPERATION OF COOPERATIVE LAW ENFORCEMENT SYSTEM OF INTELLECTUAL PROPERTY RIGHTS IN CHINA'S FREE TRADE ZONE
}

\author{
Zhai Linqing \\ School of Arts and Law, Wuhan University of Technology, Wuhan, China \\ Corresponding Author Email: Zhai Linqing
}

This is an open access article distributed under the Creative Commons Attribution License, which permits unrestricted use, distribution, and reproduction in any medium, provided the original work is properly cited.

\section{ARTICLE DETAILS}

\section{Article History:}

Received 26 June 2018 Accepted 2 July 2018 Available online 1 August 2018

\section{ABSTRACT}

There are great differences between China's Shanghai free trade area and other traditional free trade zones, which not only include goods, but also the glorious mission to promote the transformation of our government's functions, service industry and new trade. And there are no other characteristics in the Shanghai free trade area in terms of intellectual property. The issue of intellectual property rights should be enlarged. In principle, the Shanghai free trade zone can be carried out in accordance with the standards. In addition to the innovation of the law enforcement, the Shanghai free trade area needs to build a diversified solution system for intellectual property disputes, promulgate the effective countermeasures in accordance with the law, and promote the liberalization of China's trade and investment, and achieve the strategic goal of "building China's economic upgrading version" and effectively protect our country's knowledge production. The basic interests of the right person.

\section{KEYWORDS}

Free trade area, intellectual property, law enforcement system, design and operation.

\section{INTRODUCTION}

Nowadays, China's free trade area has encountered many challenges in the process of construction. Although the free trade area has achieved good achievements in the process of development, there are also many problems in the process of practice [1]. According to research, $t$ mainly embodies the typical local problems in the course of the development of the free trade area, and the system of each area is created [2]. New, both grassroots governments, reform rights and enforcement capabilities have encountered some pressure and obstacles. At the same time, the starting point and the stock of each area are very different, so the innovation and effect of the system are also quite different [3].

2. CHINA'S FREE TRADE AREA INTELLECTUAL PROPERTY COORDINATION LAW ENFORCEMENT SYSTEM DESIGN AND OPERATION

Based on a study, the free trade zone inevitably occurs when the trade is transferred, and the signing of different free trade agreements at every time makes the transfer of trade more complicated, because the time, the transition period, the content of the preferential arrangement and so on are different for each free trade agreement, which will lead to the transfer of trade many times and the appearance of overlapping [4]. According to research, it requires the trade policy of both sides to coordinate and reduce the losses caused by preferential trade [5].

In the free trade area, more than two sovereign states and separate customs areas have signed agreements, and under the premise of the most preferential treatment of the WTO, the market is developed in depth [6]. Many goods tariff and non-tariff barriers are cancelled in different periods and stages, and the market access conditions for service and investment are improved. In order to achieve the goal of liberalization of trade and investment. From the traditional trade zone and the current free trade area, the traditional FTA includes trade in goods, rules of origin and the settlement of disputes; the current free trade area includes the contents of the appeals, including service trade, trade investment, investment liberalization, intellectual property rights and so on [7]. Li Shanmin, Dean of the Comprehensive Research Institute of the free trade area of Zhongshan University, pointed out that the FTA must innovate in four key areas, so as to seize the opportunities for development. First, the free trade area needs the advantages of the test zone system of the free trade zone and the strengthening of the reform of the administrative system. Second, and the use of the rights and responsibilities of the government to standardize the work, to provide a template for the further reform of the country. Third, the market supervision system centered on the construction of social credit system and create the environment of the rule of law and internationalization. Fourth, build the free trade area into a stage of opening to the outside world, and actively respond to the advanced TPP system.

3. STARTING FROM REALITY, THE BASIC PROBLEMS AND INTERNATIONAL PRACTICE OF INTELLECTUAL PROPERTY PROTECTION IN FREE TRADE AREA ARE ANALYZED CONCRETELY.

\subsection{Basic issues of trade facilitation and intellectual property}

3.1.1 Regional conflicts between free trade zones and intellectual property rights protection

The free trade area has become a field of special customs supervision policy in China. According to the principle of sovereignty and territoriality of our country, the law of intellectual property in our country is in accordance with the free trade zone, so the intellectual property rights should be protected. Due to the particularity of the FTA, the border between the border and the market has been separated, so there is a regional conflict of intellectual [8].

\subsubsection{An implementation of the "first line release, second line control" regulation}

The implementation of this model in the FTA will extremely likely cause the FTA to become a high-risk area for intellectual property, because transit will include exporters, destination countries and transit countries and so on, so their laws are different, which will eventually lead to a lot of regulatory issues. 
3.2 China's bridgehead to tackle the new international challenges of intellectual property: Shanghai FTA pilot area

\subsubsection{China is under constant pressure from unilateral intellectual property protection measures.}

In the international economic competition, intellectual property rights also play an important weapon. Most of the countries have promulgated and formulated the intellectual property strategy which conforms to their own basic conditions. With the rapid development of international intellectual property rights protection and the more open intellectual property rights background, our country must make out the knowledge. The strategy of intellectual property rights guarantees China's technological safety and promotes China's independent innovation capability and restricts the abuse of intellectual property rights of transnational enterprises [9].

The Shanghai free trade area has encountered many problems in the process of development. One of the main problems is gradually facing the pressure of the international protection measures of unilateral intellectual property rights. Because of the strong awareness of the protection of intellectual property in foreign countries, many regulations on the protection of its own intellectual property rights have been released, and the Shanghai free trade area has been brought. There are many challenges and difficulties in order to protect the intellectual property rights of Shanghai and our country. Therefore, we must find corresponding countermeasures and solve the problem of the pressure of unilateral intellectual property protection.

\subsubsection{The new TRIPS rules on international intellectual property rights} will have an important impact on China.

At present, the new rules of international intellectual property rights beyond TRIPS obligations have brought great influence on our country. The Shanghai free trade area has built its own rules and management system of intellectual property protection under the state permission, but the international rules of intellectual property rights have been changed and updated, and it is also given to the Shanghai free trade area, as well as in China. His free trade area has brought a problem. How to adapt to the new rules of international intellectual property rights has become a question to be considered in the Shanghai free trade area. How to give full play to the advantages brought by the new rules and to reduce the negative impact of the new rules on our country have become the questions that we should pay attention to in the future.

The international intellectual property protection system has developed rapidly after the TRIPS agreement has been issued by the century trade organization. These developments also make the developing countries more and more burdens on the whole, and the differences and preferences obtained by the developing countries will be greatly affected, which will make the economic development of the developing countries receive one. Therefore, the international community needs to focus on this issue and promote the development of an international protection system for intellectual property rights in a rational direction.

\subsubsection{Exploration and trial of high standard protection rules for intellectual property rights in Shanghai pilot Free Trade Zone}

In order to connect with the new international rules, the Shanghai self trade test area takes the lead in the exploration and application of the high standard rules of intellectual property rights and provides guidance for other areas of our country and gives guidance to other free trade areas, wants to better integrate with the country and better protect the intellectual property of our country [10]. Therefore, it must be suitable. According to the new international standards, we can find countermeasures to protect China's intellectual property rights and deal with the difficulties caused by the new rules.

\section{EMPIRICAL ANALYSIS}

4.1 Taking the Shanghai free trade pilot zone as an experimental field for the reform of China's intellectual property rights protection system

4.1.1 Exploration and practice of intellectual property system innovation in Shanghai free trade pilot area

Based on a study, since the establishment of the Shanghai free trade area, the model of negative list management, the "single window" of international trade, the financial macro Prudential Management System and so on, a series of basic core system innovations are carried out [11]. After that, the Shanghai free trade area will carry out systematic and systematic innovation and adhere to the system innovation as the main center point. Holding the highest international standards of benchmarking, the integration of the reform system is more reflected, and a comprehensive reform pilot area that combines openness and innovation is built. Since the establishment of the Shanghai free trade zone test area, according to China's market economy and the opening to the requirements, and to explore and build a government function as the center of the six-basic system of supervision after the post. There is a security review system, an anti monopoly review system, a perfect social credit system, an annual report of the enterprise and an abnormal list system, perfect information sharing and comprehensive law enforcement system, and the construction of a social force to participate in the market supervision system. The practice of the innovation of the intellectual property system in the pilot area of the Shanghai free trade zone has also provided reference and assistance to other FTA in China.

\subsubsection{Challenges and problems of intellectual property management and protection in Shanghai free trade pilot area}

There are also some problems in the innovation of intellectual property system in Shanghai pilot free trade zone. First is the problem of intellectual property administration and protection innovation. It includes the problems of the integration and function of the administrative departments of intellectual property rights, the integration of the internal institutions and functions after the "three in one" system of the Intellectual Property Office, and the lack of effective grasp of the intellectual property management in the experimental area. After the establishment of the Intellectual Property Office of the Shanghai self trade test area, the scope of the work will be from the original. The limited examination and approval items are extended to more extensive administrative functions, which mainly undertake the administrative management of the unified intellectual property in the experimental area, carry out the key fields, key industries, the protection of the major special intellectual property rights, promote the construction of the intellectual property service system, and promote the unified intellectual property rights of the transformation and application of intellectual property rights. The function of public administration. Because most of the industrial development in the experimental area is still in the stage of introduction and layout, it is short of concrete grasp of the public service of intellectual property, and it also takes a certain time to develop the public service function in an all-round way. Secondly, there are still several problems in the judicial protection of intellectual property in Shanghai pilot free trade zone. First, the question of the reform of the "three in one" trial. Although the intellectual property court has been established in the pilot area, the "three in one" trial has not yet been implemented. At present, a number of intellectual property rights, such as patents, trademarks, copyrights and trade secrets, are divided into civil, criminal and administrative cases of intellectual property, which belong to civil courts, administrative tribunals and criminal trials, respectively. Second, procedural problems restrict the efficiency of judicial cases. First of all, the issue of extraterritorial identification of foreign-related and internationally renowned enterprises. The intellectual property disputes accepted by courts in Shanghai pilot free trade zone are characterized by a large proportion of foreign-related cases and prominent characteristics of famous enterprises and famous brand cases. The second is the judicial identification of intellectual property rights. In the judicial trial of intellectual property disputes in the Shanghai self trade test area or in the region, the investigation of the legal facts is often restricted by the professional and technical nature, which often restricts the promotion of the efficiency of the trial. Third, the complexity of the law applicable to the characteristics of the FTA. Finally, we should establish the problems faced by diversified intellectual property dispute settlement mechanisms.

Including non-litigation dispute resolution is still lacking in attractiveness and lack of full cohesion within the multiple dispute resolution mechanism. In the face of these challenges and problems, suggestions on further innovation of the intellectual property system in Shanghai pilot free trade zone are put forward. The leading role of intellectual property in the development of the Shanghai self trade test area is becoming more and more important because of the deepening of the reform and innovation in the construction of the Shanghai self-trade test area. 
4.1.3 Gestions on further innovation of intellectual property system in Shanghai pilot Free Trade Zone

(1) Strengthening the management and enforcement of intellectual property rights

The "first line opening" of the Shanghai free trade area is easy to cause the free trade area to be a warm bed of intellectual property rights infringement. Therefore, it is necessary to strengthen the management of intellectual property rights in the free trade area. In our country, the number of intellectual property infringement cases is increasing. Our country has relaxed the management of the Shanghai free trade area, but it can not relax the management of its intellectual property rights and make it the most representative area of the protection of intellectual property rights and the ability to combat intellectual property infringement in our country.

(2) Establishment of a public service platform for intellectual property rights in the free trade area

The public platform of intellectual property can provide various consultations, apply for agency assistance and so on. However, the construction of the public service system of intellectual property rights in our country is still in the period of exploration. Although the intellectual property rights support center has been built, it is still relatively backward in comparison with the developed countries.

4.2 Leveraging the Shanghai free trade pilot zone to promote a strong breakthrough in the modern intellectual property service industry

\subsubsection{Significance of developing intellectual property service industry} in Shanghai free trade pilot area

It is of great practical significance for our country to actively explore the intellectual property service industry in the Shanghai self trade test zone in China. First, it can promote innovation in the application process of our intellectual property rights and explore the path to meet the basic national conditions of our country. The glorious mission of Shanghai self trade test area is the reform and opening up of China. The direction of future development is also meeting the important contents of the eighteen Third Plenary Session of the CPC. Second, making trade and investment more liberalized and facilitating, promoting the liberalization and facilitation of trade and investment is the main function of the Shanghai self-trade test area.

The current international relations of intellectual property and trade and investment are gradually close. Both of them can not be divided into one, and the Shanghai free trade area uses a negative list to increase investment opening. And support the investment of some high-tech and service industries. Compared with developed countries, China's intellectual property service is still in the primary stage of development. Therefore, in the process of future development, we should continue to innovate and draw lessons from the experience of intellectual property innovation and development in developed countries.

\subsubsection{Practice of promoting the opening and development of} intellectual property service industry in Shanghai free trade pilot area

The further development of the service industry in the Shanghai self trade test area and the relaxation of our policy, and the service demand of most international intellectual property rights, can promote the deep development of the intellectual property service industry in the Shanghai free trade area and improve the core competitiveness of the intellectual property service industry of our country. Since the establishment of the Shanghai free trade area, it has been actively taking the initiative to carry out institutional innovation of intellectual property rights, consistently adhering to its own bottom line, avoiding the loss caused by risk, and as the leader and pioneer of the practice of intellectual property in the free trade area of China, and has made great achievements. The innovation of intellectual property in the Shanghai free trade area has a certain significance for the intellectual property of our country. After the construction of the Shanghai free trade area, many administrative management and law enforcement system related to intellectual property, the protection of Customs Intellectual Property, the solution and service industry have already completed their own innovation system and have been developed. Cheng has been verified, and it has also provided guidance for other regions in China.
4.3 The development of modern knowledge service industry in Shanghai pilot area

\subsubsection{Determination of protection standards}

According to the provisions of TRTPS, each country can carry out legislation to determine its own intellectual property within the scope of TRIPS and determine the basis for the protection of intellectual property right in accordance with the basic national conditions of the country However, the protection of the intellectual property rights in the free trade area is based on the provisions of the TRIPS and is the same as in other parts of the country or the analysis of its own. The main challenge to the protection of intellectual property rights in the free trade area is to enhance the standards of intellectual property protection in the free trade area.

\subsubsection{The choice of law enforcement mode}

Because in the law enforcement of intellectual property, our country has used the decentralized mode, and manages the patent rights, the trademark rights and the right to work from various administrative agencies. However, with the increasing number of intellectual property services in the free trade area, this model will not meet the development needs of the free trade area, so it is not satisfied with the efficient original. Under such a background, can we set up a comprehensive administrative law enforcement agency to unify the enforcement of intellectual property rights in the free trade area?

\subsubsection{The application of law in the free trade area}

The application of the law is a major issue in the court trial of the Shanghai free trade area. The tribunal of the free trade area should comply with domestic laws and international treaties in the process of verifying the case, but whether the court of the free trade area is applicable to the law is different from that of other courts in China.

\section{CONCLUSION}

The legal system of intellectual property in our country is constantly perfected, but there is still a difficult problem of law enforcement of intellectual property rights, because the court in the enforcement of compulsory enforcement is insufficient, and the parties who have encountered intellectual property disputes will be prosecuted. This paper, starting from the liberalization of trade and investment in free trade area, combines theory with practice, and studies and analyzes the design and operation of cooperative law enforcement system in the perspective of intellectual property rights in China's free trade area, and provides corresponding countermeasures for China's free trade area.

\section{REFERENCES}

[1] Zhu, B.Q. 2016. Study on the Legal System of the Negative List of Shanghai Free Trade Zone. Knowledge Economy (3).

[2] Tang, J. 2016. New Progress and Future Challenges of the Shanghai Free Trade Zone Construction Plan. China Economic and Trade Guide (3).

[3] Zhao, B.Y. 2016. Multi Angle Analysis of China's "Free Trade Zone" Building. National Governance (12).

[3] Wang, L.L. 2016. Free Trade Zone Strategy Speeded up. China's Foreign Trade (3).

[4] Freya, L. 2016. The Background, Significance and Impact on Commercial Banks of Establishing FTA. Chinese Business Theory (29).

[5] Li, H. 2015. Policy Analysis and Outlook of China's Four Major Free Trade Zones. China's Collective Economy (31).

[6] Li, X.H., Tang, S. 2015. FTA Financial Innovation Path. China Foreign Exchange (14).

[7] Jing, L.B., Yuan, P.H. 2015. Evaluation of the Development of China (Shanghai) Free Trade Pilot Zone. International Economic Review (5). 
[8] Zhu, B.Q. 2016. Study on the Legal System of the Negative List of Shanghai Free Trade Zone. Knowledge Economy (3).

[9] Tang, Y. 2016. Constitutional Expression of the Rights of Ethnic
Minorities. Zhejiang Journal (3).

[10] Yang, J.F., Zhang, L. 2016. China's Free Trade Pilot Area Intellectual Property System Innovation. FTA Research Series (8). 